\title{
An English Oblique Translation Analysis of "Twitter" Social Networking Website into Indonesian: An Applied Linguistics Study
}

\author{
Herman, Juniyati Rajagukguk \\ Department of English Education, Nommensen HKBP University, Medan, Indonesia \\ Email address: \\ herman@uhn.ac.id (Herman),juniyatirajagukguk2@gmail.com (J. Rajagukguk)
}

To cite this article:

Herman, Juniyati Rajagukguk. An English Oblique Translation Analysis of "Twitter" Social Networking Website into Indonesian: An Applied Linguistics Study. International and Public Affairs. Vol. 3, No. 1, 2019, pp. 6-12. doi: 10.11648/j.ipa.20190301.12

Received: June 18, 2019; Accepted: July 15, 2019; Published: July 26, 2019

\begin{abstract}
The objective of this research is to analyze and find out the oblique translation through the terms and sentences from English version into Indonesian version. Social media like Twitter is one of many media that are used by people to communicate for near or far direction. To be able to use the media, translation is needed in order to have a good understanding in communication. Since its importance, this research is conducted in order to analyze a translation from one social networking website, twitter, which is served into bilingual version, English and Indonesian. The data is analyzed through a translation theory stated by Vinay and Darbelnet. The theory divides the method of translation into 2 main parts, (1) literal or direct translation which covers borrowing, calque, and literal translation. Meanwhile (2) an oblique translation, which is also called as translation procedures, serves transposition, modulation, equivalence, and adaptation. The research method in this research used is qualitative description. The data are taken from each sentence written in English (as Source Language/SL) into Indonesian (as Target Language/TL). After describing a translation theory about definition and translation procedures, it can be concluded that all procedures (oblique translation) are used and found in one social networking service, twitter. They are transposition, modulation, equivalence, and adaptation.
\end{abstract}

Keywords: English, Indonesian, Oblique, Translation Transposition, Modulation, Equivalence, Adaptation

\section{Introduction}

Communication is a way for human interacts with the other. The interaction can be served into oral and written one. In the past, the main problem for human to interact or have a communication is the distance because they usually had the communication via orally. The best way to communicate in a far distance is by having a letter (written). Nowadays, communication is not only done orally (face to face) but also can be done via technology in present. By the development of technology, communication can be done without caring about the distance. The most common media communication used in our daily life will be radio, television, newspaper, and of course telephone takes a very important part in communication. Nowadays, the media is added and even though developed based on the technology development into internet services, website, blogging and web feeds. The Internet has also enabled or accelerated the creation of new forms of human interactions through Instant messaging, Internet forums and Social Networking sites.

Based on http://en.wikipedia.org/wiki/Social_networking_service, $28^{\text {th }}$ December 2013; 10:29am, A social networking service is a platform to build social networks or social relations among people who, for example, share interests, activities, backgrounds, or real-life connections. There are so many kinds of social networking services like facebook. com, twitter. com, Linkedln.com, Google+, MySpace, etc. One of the most popular social networking being used, besides facebook.com, in worldwide is twitter. com. Twitter is an online social networking and microblogging service that enables users to send and read "tweets", which are text messages limited to 140 characters. Twitter was created in March 2006 by Jack Dorsey, Evan Williams, Biz Stone and Noah Glass and by July 2006, the site was launched. The service rapidly gained worldwide popularity, with 500 
million registered users in 2012, who posted 340 million tweets per day. The service also handled 1.6 billion search queries per day. (http://en.wikipedia.org/wiki/Twitter, $28^{\text {th }}$ December $2013 ; 10.41 \mathrm{am})$. Anyone can sign up freely and only the registered users can read and post tweets, but unregistered users can only read them. That is why everyone in the world can use and play twitter to get some information and communicate with the other. Of course, one main point that makes twitter can be played and used is the available of the various language. Twitter has already been translated into about 33 different languages, including Bahasa Indonesia. In having the twitter as communication, of course, understanding the various kinds of languages is the most importance one. One way to understand the different languages is by having translation.

Translation is transferring a text (source language) into another language (target language) without changing the message. A translator should understand the message and written source language (SL) in order to transfer into target language (TL). Catford defined translation as the replacement of textual material in the other language (TL) [2]. Moreover, Bell defines the phenomenon as "the replacement of a representation of a text in one language by a representation of an equivalent text in a second language." [1]

Nida and Taber stated that translation consists in reproducing inthe receptor language the closest natural equivalent of the source language message, first in terms of meaning and secondly in terms of style" [8]. Based to the definition, translating means transfer the message from SL into TL. The message in TL should have the equivalence and closely meaning with the SL.

Translation has many procedures or methods. So, in translating the translator may uses procedures in the process of doing both of the source language (SL) and target language (TL). There is a difference between translation method and translation procedures [7]. He writes that, while translation methods relate to whole texts, translation procedures are used for sentences and the smaller unit of language. Vinay and Darbelnet in Venuti mention that the method or procedure of translation can be divided into two covering procedures, they are (a) literal or direct translation; consists of Borrowing, Calque, and Literal translation, and (b) oblique translation; consists of Transposition, Equivalent, Modulation and Adaptation [10].

In this paper, the researcher conducts a research of translation in Source Language (in English) into Target Language (in Bahasa Indonesia). In this occasion, the researcher only focuses to the oblique translation in making the research for this paper. The object of this research is the Source Language (SL) and Target Language (TL) that found in a social networking service, twitter. com. In twitter. com, there are many options to be browsed such as home, discover, connect, me, direct message, settings and help. The researcher is interested in analyzing and finding whether the theory of translation procedures mentioned by Vinay and Darbelnet is applied or not after the researcher used and read the available languages, English and Indonesia, in twitter. com. For that reason, the researcher makes the analysis of translation through translation procedures (Oblique translation) in twitter. com. It is hoped that this research will give contribution to the teachers and the students who study the translation.

\subsection{Problem of the Research}

Based on the above explanation, the problem created as the following:

What kinds of oblique translations are found in English "twitter" social networking service into Indonesia?

\subsection{Objective of the Research}

The objective of this research is to answer the problem as what have been mentioned in the previous point. It is to analyze and find out the oblique translations found in English "twitter" social networking service into Indonesia.

\subsection{Scope of the Research}

Translation consists of many types of aspects such as shifts and procedures. Based on Vinay and Darbelnet's theory, translation procedures are divided into 2 main parts, (1) literal or direct translation which covers borrowing, calque, and literal translation. Meanwhile (2) an oblique translation serves transposition, modulation, equivalence, and adaptation As mentioned in background, it is said that in twitter. com, there are also so many option to be such as home, discover, connect, me, direct message, settings and help. On this occasion, the researcher will focus on analyzing and discussing the oblique translation through "twitter" as social networking service into Indonesia, especially to the option of help in twitter. com.

\section{Theoretical Review}

\subsection{Translation Theory}

Nowadays, translation shows its importance in human's life. The importance can be seen from how people communicate and understand each other. Communicating and understanding are related to how get the meaning. The process to get the meaning can be obtained by translation since there are many different languages in the world. That's why the study of translation is needed even though it cannot give solution to many problems, especially in translation. The study of translation cannot be separated to the theory of translation although translation is usually refers to the practice. The understanding about general concept of translation theory is very important and useful for the translators. So, it is impossible for the translators to get a good translation without understanding the meaning or definition of translation, because translation is as general concept of translation theory.

Translation theory is not always relevant with the translating practice and the teaching of translation. The theory of translation is focused at characteristic and the translation problems as a phenomenon. According Lauven - 
Zwart (1985) in Nababan, it is that producing the better translating and translations are not the main purpose of translation theory. A better translating and translation it is just the theory product and method of translating.

Discussing translation theory will be endless because various perspectives from different experts also give the same impact and understanding to translation. Since translation is related to linguistics, the approach of translation theory is focusing to the meaning, equivalence, and shifts which are introduced by some experts like Roman Jakobson, Eugene Nida, Vinay, Darbelnet, Munday, Catford, and Lauven-Zwart.

\subsection{Definition of Translation}

Generally, translation is known as the process of transferring one language (known as Source Language) to another language (known as Target Language). Meanwhile, some people try to define translation in different version. According to Catford in Machali, translation is the replacement of textual material in one language (SL) by equivalent textual material in another language (TL) [6]. It means that the translation is changing of the text material of the source language (SL) to the target language (TL) which in the target language the text has the equivalence in the source language. Newmark also gives the same definition about translation [7]. He defines translation is rendering the meaning of a text into another language in the way that the author intended the text. Hence, Catfordas cited in Herman define translation is the replacement of textual material in one language (SL) by equivalent textual material in another language (TL) [4]. On the other hand, Larson as cited in Herman stated that translation in the transfer of meaning in the source language text into the target text, this is done by replacing the form of the first language by the form of the second language [5]. The product involves the translated text and the process involves the translator changing an original written text (source language) into written text (target language) in different verbal language.

Based on the various definitions above, the researcher can conclude that translation involves two languages; they are Source language (SL) and Target Language (TL). So, translation is a process of transferring the message, meaning, statement, utterance of the SL to the TL, and his product of translation is from the author's perspective.

\subsection{Translation Procedures}

The previous definition above is talking about the translation which covers source language and target language. In order to achieve a good target language, methods or procedures in translation are inevitable. Venuti in Herman identified two general methods that comprise seven procedures in translating source text to target text. The two methods are Direct Translation and Indirect (Oblique). Direct translation covers borrowing, calque, and literal translation while oblique translation covers transposition, modulation, equivalence, and adaptation [5].

\subsubsection{Direct Translation}

Literal or direct translation procedures are used when structural and conceptual elements of the source language can be transposed into the target language. According to Vinay and Darbelnet, there are three procedures of Direct or Literal Translation; they are Borrowing, Calque, and Literal Translation.

\section{(i) Borrowing}

Vinay and Darbelnet in Venuti say that Borrowing is the simplest of all translation procedures. In borrowing procedure, the Source Language is directly transferred to the Target Language [10]. In other words, this procedures means that one language borrows an expression form from another language.

According to Haugen in Herman, there are some possibilities that may occur in this procedure. First, borrowing with no change in form and meaning (pure loanwords), the second, borrowing with changes in form but without changing the meaning (mix loan), and the third, borrowing when part of the term is native and other part is borrowed, but the meaning is fully borrowed (loan blends) [5] Examples:

a. Borrowing with no change in form and meaning (pure loanwords)

$\begin{array}{ll}\text { Source Language (SL) } & \text { Target Language (TL) } \\ \text { Radio } & \text { Radio } \\ \text { Supermarket } & \text { Supermarket } \\ \text { Charger } & \text { Charger }\end{array}$

b. Borrowing with change in form but without change the meaning (mix loanwords)

$\begin{array}{ll}\text { Source Language (SL) } & \text { Target Language (TL) } \\ \text { Inflation } & \text { Inflasi } \\ \text { Business } & \text { Bisnis }\end{array}$

c. Loan blend (borrowing when part of the term is native and the other part is borrowed)

$\begin{array}{ll}\text { Source Language (SL) } & \text { Target Language (TL) } \\ \text { National debt } & \text { Hutang nasional }\end{array}$

(ii) Calque

Calque is a phrase borrowed from another language and translated literally word for word. Vinay and Darbelnet in Venuti say that a calque is a special kind of borrowing whereby a language borrows an expression from another, but then translates literally each of its elements [10]. Vinay and Darbelnet in Venuti define the result of calque: first, a lexical calque, which respects the syntactic structure of the TL, whilst introducing a new mode of expression, the second, structural calque, introduces a new construction into the language.

Examples:

$\begin{array}{ll}\text { Source Language (SL) } & \text { Target Language (TL) } \\ \text { Crisis management } & \text { Manajemen krisis }\end{array}$

(iii) Literal Translation

Literal translation is also called as word for word translation. It is the direct transfer of a SL text into a 
grammatically and idiomatically appropriate TL text in which the translators' task is limited to observing the adherence to the linguistic servitudes of the TL. In principle, a literal translation is a unique solution which is reversible and complete in itself.

There are other examples of literal translation.

Examples:

Source Language (SL)

All the mice

\subsubsection{Oblique Translation}

Oblique translation occurs when word for word translation is impossible. Oblique translation procedures by Vinay and Darbelnet, consist of four types. The first is transposition, the second is modulation, the third is equivalence, and the last is adaptation.

(i) Transposition

Vinay and Darbelnet in Venuti define transposition is a procedure that involves replacing one word class with another without changing the meaning of the message or the sense [10]. Transposition also involves replacing one word class with another without changing the meaning of the message. On the other hand, transposition is also a change in the grammar from source language to target language (singular to plural; position of the adjective, changing the word class or part of speech). In translation, there are two types of transposition, namely obligatory transposition and optional transposition. Obligatory transposition occurs when the target language has no other choices because of the language system.

Examples:

$\begin{array}{ll}\text { Source Language (SL) } & \text { Target Language (TL) } \\ \text { Long grass } & \text { Rerumputan yang tinggi }\end{array}$

An optional transposition is a transposition that, for the sake of style, can be chosen by the translator if it fits better into the utterance.

Examples:

\section{Source Language (SL) \\ Medical student \\ Standard of living \\ Password}

\author{
Target Language (TL) \\ Mahasiswa kedokteran \\ Standar hidup \\ Kata sandi
}

(ii) Modulation

Modulation is a variation of the form of the message, obtained by a change in the point of view. This changes the semantic and point of view of the Source Language. As with transposition, there are two types of modulation, free or optional modulation and fixed or obligatory modulation. Free or optional is generally adopted because of nonlinguistic reason. It is mostly used to stress the meaning, to affect coherence or to find out natural form in the TL.

Examples:

$\begin{array}{ll}\text { Source Language (SL) } & \text { Target Language (TL) } \\ \text { Black and blue } & \text { Lebam } \\ \text { He was killed in the war } & \text { Dia gugur dalam perang }\end{array}$

Fixed or obligatory modulation occurs when a word, phrase or structure cannot be found in the TL. When an active sentence is translated into a passive one, this is an instance of this type of modulation.

Examples:
Source Language (SL)

I grew up in Jakarta
Target Language (TL)

Saya dibesarkan di Jakarta
The difference between fixed and free modulation is one of degree. In the case of fixed modulation, translators with a good knowledge of both languages and freely used this method, as they will be aware of the frequency of use, the overall acceptable, and the confirmation provided by a dictionary or grammar of the preferred expression.

(iii) Equivalence

Vinay and Darbelnet use this term to refer to cases where languages describe the same situation by different stylistic or structural methods [10]. This procedure means that the process of translating one language into another language that emphasizes on closest natural meaning

Example:

Hello $\rightarrow$ Selamatpagi, selamatsiang, Horas, etc

'Hello' has many functions. The TL in Indo has many variations, but from its function, is for communication

Another examples:

$\begin{array}{ll}\text { Source Language (SL) } & \text { Target Language (TL) } \\ \text { Miaou } & \text { Miaow } \\ \text { Cock-a-doodle-do } & \text { Kukuruyuk }\end{array}$

Equivalence is also particularly useful in translating idioms and proverbs.

For examples:

$\begin{array}{ll}\text { Source Language (SL) } & \text { Target Language (TL) } \\ \text { Bookworm } & \text { Kutu buku }\end{array}$

(iv) Adaptation

Vinay and Darbelnet in Venuti define adaptation as a procedure that creates a new situation to indicate a situational equivalence [10]. And also it involves changing the cultural reference when a situation in the source culture does not exist in the target culture. Adaptation is used in those cases where the type of situation being referred to by the SL message is unknown in the TL culture. In this case, a translator can create a new situation that can be considered equivalent.

Example:

Your Sincerely (SL) is translated into DenganHormat(TL).

Based on the explanation above, now we know about translation, whether it's about the meaning, process, functions, technical, procedures or methods, and so on. Every kinds of translation have a different meaning that is based on the researchers. If we know about the meaning kinds of translation, so we know how to analyze the text by using the procedure.

In transferring the message from SL into the TL, the translator should add or omit some the information in order to have natural translation and the naturalness of the translated work can be realized if the Target Language Text 
is read and the readers feel that it is not like translated text. This definition expresses the idea that if we want to have the meaning of words or phrase, it must be in the context of sentence. An example is in sentence like this: 'The man who had pressed the remote control device' and the translator translates it into 'Lelaki yang barusajamenekantombolalat control jarakjauh'. In this case the translator necessary gives addition of information in translating the underlined nominal group construction by the word tombol which is not stated in the SL

Other Examples:

$\begin{array}{ll}\text { Source Language (SL) } & \text { Target Language (TL) } \\ \text { You } & \text { Ibu } \\ \text { Hide and seek } & \text { Petak umpet }\end{array}$

Some of the source language data do not have exact equivalents in the target language because of the different cultural backgrounds between the source language and target language. Therefore, not all of the source language terms can be translated into the target language if the source language terms are considered as not having the equivalents, for example English borrowing word 'orang utan' is from Bahasa Indonesian.

\section{Research Method}

This chapter discusses about the method and procedure that are used to solve the problem of the research. The researcher has written some theories in the previous chapter in order to describe research design, data collecting method, and data analyzing method

\subsection{Research Design}

In this paper, this research is conducted in qualitative library research which the data is from Source Language into Target language. Library research is a research that is done in library where a researcher faces many kinds of literatures that is suitable with the objective and problem of the analysis.

\subsection{Data Collecting Method}

The data source was taken from "twitter" social networking service and its translation into Indonesia. In "twitter", there are parts/options such as home, discover, connect, me, direct message, settings and help. In twitter.com of help, there are many options such as (1) Welcome to twitter, (2) Me, (3) Connect, (4) Discover, (5) Mobile and Apps, (6) Troubleshooting, (7) Policies \& Violations, (8) Safety \& Security, and (9) Advertising.

In order to make the research more efficient and accurate especially in conserving money, times and energy), the researcher takes the data at random. It called systematical random sampling. Riduwan says Sampling Sistematisialahpengambilansampeldidasarkanatasurutandari populasi yang diberinomorurut. Setelahpemberiannomorurut, pengambilansampeldapatdilakukanberdasarkannomorgenap atauganjilataudengannomorkelipatannya.t ('Systematical sampling is a sample making based on the turn of population that has already given the line numbers, sample making could be done based on even numbers odds numbers or even double numbers) [9]. From explanation, the researcher takes the data from even numbers, they are (2) Me, (4) Discover, (6) Troubleshooting, and (8) Safety \& Security.

\subsection{Data Analyzing Method}

In this research, the method used in analyzing the data is Qualitative. Qualitative method is applied by describing or explaining the data from a social networking service "twitter". Qualitative method means an analysis which uses some instruments for collecting the data. According to Bogdan and Biklen, "qualitative research is descriptive which it means the data collected are in the form of words of pictures rather than number'.

The data is analyzed in two steps. First, the researcher tabulated all of the selected data consisting of oblique translation procedures. Second, the researcher categorized and classified the kinds of oblique translation procedures.

Following are the steps done in collecting and analyzing the data:

1. Collecting the data from "twitter"

2. Reading and identifying the data source

3. Analyzing the data and find out the oblique translation procedures

4. Giving discussions and making the conclusion with its suggestion

From the procedures above, the researcher tries to analyze the data to find out the oblique translation procedures. After that the researcher draws tables for making classification of each transposition, modulation, equivalence, adaptation.

\section{The Result of Research}

\subsection{Research Findings}

After analyzing the data, the researcher found in his research that all kinds of oblique translations procedures found in "twitter" as social networking service. The oblique translation procedures used are: transposition, modulation, equivalence, and adaptation.

\section{A. Transposition}

Vinay and Darbelnet in Venuti define transposition is a procedure that involves replacing one word class with another without changing the meaning of the message or the sense.

Some examples of transposition found in "twitter" English version into Indonesia version are as follow: 
Table 1. Transposition Procedure in Twitter.

\begin{tabular}{|c|c|c|}
\hline No & Source Language (SL) & Target Language (TL) \\
\hline 1 & Password & Kata sandi \\
\hline 2 & Settings & Pengaturan \\
\hline 3 & Requiring additional information to request a password reset & Memintainformasitambahanuntukpermintaanpengaturanulang kata sandi \\
\hline 5 & $\begin{array}{l}\text { Be sure to review the various permissions you are granting to } \\
\text { the application. These are listed in green (what the app can do } \\
\text { with your account) and red (what the app can't do) }\end{array}$ & 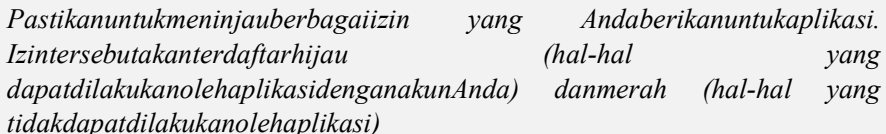 \\
\hline
\end{tabular}

B. Modulation

Modulation is a variation of the form of the message, obtained by a change in the point of view. This changes the semantic and point of view of the Source Language.

Some examples of Modulation found in "twitter" English version into Indonesia version are as follow:

Table 2. Modulation Procedure in Twitter.

\begin{tabular}{|c|c|c|}
\hline No & Source Language (SL) & Target Language (TL) \\
\hline 1 & $\begin{array}{l}\text { When you sign up for Twitter, you have the option to keep your Tweets } \\
\text { public (the default account setting) or to protect your Tweets }\end{array}$ & $\begin{array}{l}\text { Saatmendaftarke Twitter, Andamemilikiopsiuntukmembiarkan Tweet } \\
\text { Andaterbukauntukkhalayakramai (pengaturanakunbawaan) } \\
\text { ataumelindungi Tweet Anda }\end{array}$ \\
\hline 2 & $\begin{array}{l}\text { If you at one time had public Tweets, those Tweets will no longer be } \\
\text { public or appear in public Twitter Search results; your Tweets will only } \\
\text { be viewable and searchable for yourself and your approved followers }\end{array}$ & $\begin{array}{l}\text { Jikasuatu kali Andamemiliki Tweet publik, Tweet } \\
\text { ituakanselalubersifatpublikdandapatdicari, } \\
\text { meskiAndamengubahpengaturanketerlindungi }\end{array}$ \\
\hline 3 & $\begin{array}{l}\text { Please note: Deleted DMs disappear from both the sender and the } \\
\text { recipient's history. If you are missing DMs, check with the person you } \\
\text { messaged to verify that they deleted the DMs you are missing }\end{array}$ & $\begin{array}{l}\text { Perhatikan: PL yang } \\
\text { dihapusakanhilangdaririwayatpengirimdanpenerima. Jika PL } \\
\text { Andatidakmuncul, tanyakankepada orang yang } \\
\text { Andakirimipesanuntukmemverifikasikanbahwaiamenghapus PL } \\
\text { Andatersebut }\end{array}$ \\
\hline 4 & $\begin{array}{l}\text { A note about DM fails: Your service provider may split SMS messages } \\
\text { greater than } 160 \text { characters into multiple messages. In this case, the } \\
\text { second message will post as a normal Tweet because it doesn't begin with } \\
\text { d username, as the first message did }\end{array}$ & $\begin{array}{l}\text { Catatantentang PL gagal: } \\
\text { PenyedialayananAndamungkinmemecahpesan SMS yang melebihi } 160 \\
\text { karaktermenjadibeberapapesan. Dalamhalini, } \\
\text { pesankeduaakandikirimkansebagai Tweet normal } \\
\text { karenatidakdimulaidengan d namapengguna, } \\
\text { sepertipadapesanpertama }\end{array}$ \\
\hline 5 & $\begin{array}{l}\text { Want to delete your TweetDeck account? You can do so here. Please note } \\
\text { that deleting your TweetDeck account does NOT deactivate your Twitter } \\
\text { account }\end{array}$ & $\begin{array}{l}\text { InginmenghapusakunTweetDeckAnda? Andadapatmelakukannyadi } \\
\text { sini. HarapdiingatbahwamenghapusakunTweetDeck TIDAK serta- } \\
\text { mertamenonaktifkanakun Twitter Anda. }\end{array}$ \\
\hline
\end{tabular}

\section{Equivalence}

Vinay and Darbelnet use this term to refer to cases where languages describe the same situation by different stylistic or structural methods. This procedure means that the process of translating one language into another language that emphasizes on closest natural meaning.

Some examples of Equivalence found in "twitter" English version into Indonesia version are as follow:

Table 3. Equivalence Procedure in Twitter.

\begin{tabular}{lll}
\hline No & Source Language (SL) & Target Language (TL) \\
\hline 1 & Some third-party apps. Learn more here & Beberapaaplikasipihakketiga. Pelajarilebihlanjutdi sini \\
2 & Click Save changes. You're all set! & KlikSimpanperubahan. Semuanyaberes! \\
3 & $\begin{array}{l}\text { If you are not able to click the link, copy the full URL from the email and } \\
\text { paste it into a new web browser window }\end{array}$ & $\begin{array}{l}\text { JikaAndatidakdapatmengekliktautan, salin-rekatkan URL lengkapdari } \\
\text { email kejendelaperamban web baru }\end{array}$ \\
\hline
\end{tabular}

\section{Adaptation}

Vinay and Darbelnet in Venuti define adaptation as a procedure that creates a new situation to indicate a situational equivalence. And also it involves changing the cultural reference when a situation in the source culture does not exist in the target culture. Adaptation is used in those cases where the type of situation being referred to by the SL message is unknown in the TL culture. In this case, a translator can create a new situation that can be considered equivalent.

Some examples of Adaptation found in "twitter" English version into Indonesia version are as follow:

Table 4. Adaptation Procedure in Twitter.

\begin{tabular}{lll}
\hline No & Source Language (SL) & Target Language (TL) \\
\hline \multirow{3}{*}{1} & $\begin{array}{l}\text { Note: If you are having an account issue (e.g. missing } \\
\text { Tweets, incorrect follower or following counts, } \\
\text { suspicious DMs or potential account compromise), } \\
\text { deactivating and reactivating your account will not }\end{array}$ & $\begin{array}{l}\text { Catatan: Jikaadamasalahdenganakun (misalnya, Tweet hilang, salah pengikut atau jumlah } \\
\text { mengikuti, PL mencurigakanataukemungkinanpenyalahgunaanakun), } \\
\text { menonaktifkandanmengaktifkankembaliakuntersebuttidakakanmenyelesaikanmasalah }\end{array}$ \\
\hline
\end{tabular}




\begin{tabular}{lll}
\hline No & Source Language (SL) & Target Language (TL) \\
\hline & $\begin{array}{l}\text { resolve it } \\
\text { When prompted, select the privacy settings for who }\end{array}$ & $\begin{array}{l}\text { Biladiminta, pilihpengaturanprivasiuntuksiapa-siapa yang akanmelihat Tweet Anda yang } \\
\text { will see your Tweets posted to your Facebook wall. It } \\
\text { is set to public by default } \\
\text { The \# symbol, called a hashtag, is used to mark } \\
\text { keywords or topics in a Tweet. It was created } \\
\text { organically by Twitter users as a way to categorize } \\
\text { messages }\end{array}$ \\
\hline
\end{tabular}

\section{Conclusion}

After describing a translation theory about definition and translation procedures, it can be concluded that all procedures (oblique translation) are used and found in one social networking service, twitter, they are transposition, modulation, equivalence, and adaptation. Every oblique translation is depicted in the social media, twitter. This means that every translation done by anyone is inevitable to the translation procedures.

This paper has shown the analysis of translation procedure in one context. In twitter.com, the researcher found that there are many kinds of direct translation (borrowing, calque, and literal translation) when the analysis was done. More research about direct translation needs to be conducted to make further analysis in other kinds of text in order to get a better understanding of translation procedures because the researcher feels that his research is not enough yet to fulfill human's needs in further studying of translation procedures.

\section{References}

[1] Bell, R. T. (1991). Translation and translating: Theory and practice. London and New York: Longman.

[2] Catford, J. C. (1965). A linguistic theory of translation. London: Oxford University Press.
[3] Hatim, B. \& Munday, J. (2004). Translation: An advanced resource book, London/New York: Routledge.

[4] Herman. (2016). The method of translation and practices. Germany: LAMBERT Academic Publishing.

[5] Herman. (2017). Shift in translation from English into Indonesia on narrative text. InternationalJournal of European Studies. Vol. 1, No. 3, 2017, pp. 72-77. doi: 10.11648/j.ijes.20170103. 12.

[6] Herman. (2018). Translation procedures of the subtitle of film "Tanah Air Beta" from Indonesia into English. Discovery Scientific Society: Indian Journal of Arts. Vol. 8, 2018. Pp. $32-42$.

[7] Machali, R. (2000). Pedoman bagi penerjemah. Jakarta: Grasindo.

[8] Newmark, P. (1988). A textbook of translation. New York: Prentice Hall.

[9] Nida, E dan Taber, C. (1982), The theory and practice of translation. Leiden: Ej Brill.

[10] Riduwan. (2008). Metode \& teknik menyusun tesis. Bandung: Alfabeta.

[11] Venuti, L. (2000). The translation studies reader. London and New York: Routledge.

[12] Wills, W. (2001). The science of translation: Problem and method. Shanghai: Language Education Press.

[13] http://en.wikipedia.org/wiki/Social_networking_service

[14] http://en.wikipedia. org/wiki/Twitter 